\title{
HUBUNGAN KEBIASAAN MEROKOK DAN KEBIASAAN OLAHRAGA DENGAN KEJADIAN HIPERTENSI PADA PASIEN LANJUT USIA DI PUSKESMAS KELAYAN TIMUR BANJAMASIN
}

\author{
Zuhrupal Hadi \\ zuhrupalhadi@gmail.com \\ Edy Ariyanto \\ edy.ariyanto777@gmail.com
}

Universitas Islam Kalimantan (UNISKA) MAB Banjarmasin

\begin{abstract}
Hypertension gives symptoms that will continue a little market target organs, such as stroke (to the brain), coronary heart disease (for coronary arteries) and hypertrophy of the right ventricle/left ventricle hypertrophy (for the heart muscle). The general objective of this study was to determine the relationship between smoking and exercise habits to the incidence of hypertension in elderly patients at the Health Center of East Kelayan Banjarmasin.In this study using analytical survey method with cross sectional approach. Accidental sampling with sampling techniques. Data collection using interviews through questionnaires, data analysis using Chi-Square test with a significance level $(\alpha)=10 \%$. The data collected were analyzed using statistical univariate, bivariate analysis using chi square test with the help of computerization. The results obtained by analysis of the respondents who had diarrhea in Puskesmas kelayan Timur Banjarmasin city as much as $54.2 \%$. Variables significantly associated with the incidence of diarrhea $(\mathrm{p}<0.1)$ is exercise habits. Advice can be given in this study is to health centers for improvement of East Kelayan extension given to increasing public knowledge increases. For the elderly who need to avoid developing hypertension risk factors hypertension. For further research are expected to conduct research on other risk factors.
\end{abstract}

Keywords: Smoking, Exercise Habits, Hypertension.

\section{PENDAHULUAN}

Hipertensi adalah keadaan peningkatan tekanan darah yang memberi gejala yang akan berlanjut kesuatu organ target, seperti stroke (untuk otak), penyakit jantung koroner (untuk pembuluh darah jantung) dan hipertrofi ventrikel kanan/left ventricle hypertrophy (untuk otot jantung).Dengan target organ di otak yang berupa stroke yang membawa kematian yang tinggi. Banyaknya penderita hipertensi diperkirakan sebesar 15 juta bangsa Indonesia tetapi hanya $4 \%$ yang 
controlled hypertension.Yang dimaksud dengan hipertensi terkendali adalah mereka yang menderita hipertensi dan tahu bahwa mereka menderita hipertensi dan sedang berobat (Bustan, 2007).Prevalensi hipertensi di seluruh dunia, diperkirakan sekitar 15-20\%, hipertensi lebih banyak menyerang pada usia setengah baya pada golongan umur 55-64 tahun. Hipertensi di Asia diperkirakan sudah memcapai $8-18 \%$ pada tahun 2009, hipertensi dijumpai pada 4.400 per $\quad 10.000$ penduduk. Hasil surveyKesehatan Rumah Tangga tahun 2008, prevalensi hipertensi di Indonesia sudah cukup tinggi yaitu, 83 per 1000 anggota rumah tangga, pada tahun 2009sekitar 15-20\% masyarakat Indonesia menderita hipertensi. Prevalensi hipertensi di Indonesia, pada laki-laki dari 134 (13,6\%) naik menjadi 165 (16,5\%), sedangkan hipertensi pada perempuan dari 174 (16,0\%) naik menjadi 176 (17,6\%) (Depkes RI, 2010).Hipertensi merupakan masalah besar tidak hanya di negara barat akan tetapi juga di Indonesia. Bila tidak diatasi, tekanan darah tinggi akan mengakibatkan jantung bekerja keras hingga pada suatu saat akan terjadi kerusakan yang serius. Pada jantung otot jantung akan menebal (hipertrofi) dan mengakibatkan fungsinya sebagai pompa menjadi terganggu, selanjutnya jantung akan mengalami dilatasi dan kemampuan kontraksinya berkurang (AS, 2010).Berdasarkan data dari Puskesmas Kelayan Timur penderita Hipertensi pada tahun 2010 berjumlah 2357 (11,29\%)orang dan menduduki peringkat ketiga dari 10 penyakit terbesar, sedangkan pada tahun 2011 penderita Hipertensi mencapai 3355(4,91\%) orang dan menduduki peringkat pertama dari 10 penyakit terbesar (Puskesmas Kelayan Timur, 2011).Berdasarkan data dari puskesmas kelayan timur yang di dapat dari hasil kegiatan program lanjut usia di Puskesmas Kelayan Timur pada tahun 2010 terdapat penderita hipertensi 
dengan jumlah total 177 (34,8\%) penderita, sedangkan Pada tahun 2011 terdapat penderita hipertensi dengan jumlah total 244 (38,8\%) penderita (laporan tahunan puskesmas Kelayan Timur).

Meningkatnya risiko hipertensi karena faktor keturunan tidak dapat dihindari lagi, jika kedua orang tua mengidap hipertensi. Oleh sebab itu, untuk mengurangi risiko hipertensi, anda harus dapat mengontrol faktor - faktor risiko lainnya. Faktor faktor lain yang yang mendorong terjadinya hipertensi antara lain stress, kegemukan (obesitas), pola makan, merokok dan olahraga (Indriyani, 2009).

\section{METODE PENELITIAN}

Penelitian ini merupakan penelitian yang bersifat survei analitik yaitu penelitian yang mencoba menggali bagaimana dan mengapa fenomena kesehatan itu terjadi. Penelitian ini menggunakan pendekatan cross sectional, yaitu variabel sebab akibat atau kasus yang terjadi pada objek penelitian diukur atau dikumpulkan secara simultan (dalam waktu bersamaan) (Notoatmodjo, 2005).

\section{HASIL DAN PEMBAHASAN}

\section{Analisis Univariat}

Distribusi frekuensi berdasarkan kejadian Hipertensi, Kebiasaan Merokok, dan Kebiasaan Olahraga.
Variabel yang diteliti
Frekuensi
Persentase

\section{Kejadian Hipertensi}

Normal

12

25,0

Perbatasan

10

20,8

Hipertensi

26

54,2

Kebiasaan Merokok

Tidak Merokok

37

71,7

Merokok

11

22,9

Kebiasaan Olahraga

Baik

10

20,8

Sedang

14,6 
Buruk

Berdasarkan hasil penelitian Distribusi frekuensi didapatkan kejadian hipertensi 26 responden $(54,2 \%)$, memiliki kebiasaan tidak
31

64,6

\section{Analisis Bivariat}

Tabel 4.10 Hubungan kebiasaan merokok dengan kejadian hipertensipada pasien lanjut usia di Puskesmas Kelayan Timur.

\begin{tabular}{|c|c|c|c|c|c|c|c|c|c|}
\hline \multirow[t]{3}{*}{ No } & \multirow{3}{*}{$\begin{array}{l}\text { Kebiasaan } \\
\text { merokok }\end{array}$} & \multicolumn{6}{|c|}{ Kejadian Hipertensi } & \multirow{2}{*}{\multicolumn{2}{|c|}{ TOTAL }} \\
\hline & & \multicolumn{2}{|c|}{ Normal $^{*}$} & \multicolumn{2}{|c|}{ Perbatasan* } & \multicolumn{2}{|c|}{ Hipertensi } & & \\
\hline & & $\mathrm{n}$ & $\%$ & $\mathrm{n}$ & $\%$ & $\mathrm{n}$ & $\%$ & $\mathbf{n}$ & $\%$ \\
\hline 1 & Tidak Merokok & 11 & 29,7 & 7 & 18,9 & 19 & 51,3 & 37 & 100 \\
\hline \multirow[t]{2}{*}{2} & Merokok & 1 & 9,09 & 3 & 27,2 & 7 & 63,6 & 11 & 100 \\
\hline & TOTAL & 12 & 25 & 10 & 20,8 & 26 & 54,1 & 48 & 100 \\
\hline
\end{tabular}

Keterangan : * digabung dalam analisis statistik. $\quad \mathrm{p}=0,473$ OR $=0,603$

Berdasarkan tabel 4.10 Didapatkan lanjut usia yang berobat di

hasil analisa uji statistik dengan uji Puskesmas Kelayan Timur. Lanjut

Chi-Square Testdapat dijelaskan bahwa setelah variabel kejadian hipertensi kategori normal dan perbatasan digabung diperoleh nilai signifikan $\mathrm{p}=0,473$ atau diatas nilai $\alpha=0,1(\mathrm{p}>\alpha)$ maka Ho diterima, dengan demikian secara statistik pada tingkat kepercayaan $90 \%$ tidak terdapat hubungan yang bermakna antara kebiasaan merokok dengan kejadian hipertensi pada pasien merokokberjumlah 37 responden ( $71,1 \%$, dan memiliki kebiasaan olahraga yang buruk berjumlah 31 responden $(64,6 \%)$ usia yang masih membiasakan diri dengan merokok rata-rata di usia masih 60 - 66 tahun, diatas umur tersebut sudah berhenti dengan kebiasaan merokoknya walaupun sebenarnya ada beberapa lanjut usia yang memang pernah merokok tetapi mampu menghentikan kebiasaan merokoknya karena sulit untuk bernapas selama masih membiasakan diri dengan 
merokok, karena kebiasaan merokok secara langsung dapat menimbulkan gangguan kesehatan, terutama paru-paru.Adapun penelitian ini mendapat dukungan dari Atika Sari dimana penelitiannya mengatakan bahwa dari 23 lanjut usia yang mengikuti jantung sehat di klub jantung sehat klinik kardiovaskuler RS. Hospital cinere untuk kebiasan merokok lanjut usia diperoleh hasil bahwa hampir seluruh lanjut usia tidak merokok yaitu sebanyak $91,3 \%$. Hal tersebut terjadi dikarenakan jumlah sampel sebagian besarnya adalah lansia dan banyak lansia yang sudah berhenti merokok

Tabel 4.11 Hubungan kebiasaan olahraga dengan kejadian hipertensi padapasien lanjut usia di Puskesmas Kelayan Timur.

\begin{tabular}{|c|c|c|c|c|c|c|c|c|c|}
\hline \multirow[t]{3}{*}{ No } & \multirow{3}{*}{ Kebiasaan olahraga } & \multicolumn{6}{|c|}{ Kejadian Hipertensi } & \multicolumn{2}{|c|}{ TOTAL } \\
\hline & & \multicolumn{2}{|c|}{ Normal $^{* *}$} & \multicolumn{2}{|c|}{ Perbatasan $* *$} & \multicolumn{2}{|c|}{ Hipertensi } & & \\
\hline & & $\mathrm{n}$ & $\%$ & $\mathbf{n}$ & $\%$ & $\mathrm{n}$ & $\%$ & $\mathbf{N}$ & $\%$ \\
\hline 1 & Baik* & 9 & 90 & 1 & 10 & 0 & 0 & 10 & 100 \\
\hline 2 & Sedang* & 2 & 28,5 & 2 & 28,5 & 3 & 42,8 & 7 & 100 \\
\hline \multirow[t]{2}{*}{3} & Buruk & 1 & 3,2 & 7 & 22,5 & 23 & 74 & 31 & 100 \\
\hline & TOTAL & 12 & 25 & 10 & 20,8 & 26 & 54,2 & 48 & 100 \\
\hline
\end{tabular}

Keterangan : * digabung dengan analisis statistic. $p=0,000 \mathrm{OR}=13,417$ ** digabung dengan analisis statistic.

Berdasarkan tabel 4.11 Didapatkan hasil analisa uji statistik dengan uji Chi-Square Test dapat dijelaskan bahwa setelah variabel kebiasaan olahraga kategori baik dan sedang digabung serta variabel kejadian hipertensi kategori normal dan perbatasan digabung diperoleh nilai signifikan $\mathrm{p}=0,000$ atau dibawah nilai $\alpha=0,1(\mathrm{p}<\alpha=\mathrm{p}<$ 0,1 ) maka Ho ditolak, dengan demikian secara statistik pada tingkat kepercayaan $90 \%$ terdapat hubungan yang bermakna antara kebiasaan olahraga dengan kejadian hipertensi pada pasien lanjut usia yang berobat di Puskesmas Kelayan Timur. Nilai 
$\mathrm{OR}=13,417$, menunjukkan bahawa

pasien lanjut usia yang melakukan

kebiasaan

olahraganya

baik+sedang mempunyai resiko

13,417 lebih kecil menderita penyakit hipertensi daripada pasien lanjut usia yang melakukan kebiasaan olahraganya buruk.Dari hasil penelitian ini sebagian besar lanjut usia memiliki kebiasaan olahraga yang buruk, menurut penelitian yang dilakukan melalui wawancara kebiasaan olahraga yang buruk disebabkan karena kurangnya mendapat perhatian dari orang-orang terdekat seperti keluarga, kebanyakan para lanjut usia tersebut hidup sendiri karena anak-anak mereka sudah tidak diam serumah lagi karena sudah memiliki keluarga masing-masing sehingga tidak ada menemani atau menyemangati untuk melakukan olahraga. Adapun penelitian ini didukung penelitian yang dilakukan oleh Retno Asti Werdhani dimana penelitiannya menyatakan terdapat penurunan tekanan darah pada 32,58 \% anggota dengan rata-rata penurunan tekanan darah sistolik diastolik sebesar $6 \mathrm{mmHg}$ yang dapat dipertahankan minimal selama satu bulan. Hal ini juga sesuai dengan teori bahhwa terapi untuk hipertensi untuk mengontrol tekanan darah selain dengan obatobatan dapat dilakukan dengan terapi nonfarmakologi yaitu dengan pola hidup sehat, salah satunya dengan melakukan olahraga rutin dan teratur (Sani, 2007).

\section{KESIMPULAN}

Distribusi 48 lanjut usia yang diteliti, lanjut usia yang memiliki tekanan darah normal berjumlah 12 orang (25\%), lanjut usia yang memiliki tekanan darah perbatasan berjumlah 10 orang $(20,8 \%)$ dan lanjut usia yang mengalami hipertensi berjumlah 26 orang (54,2\%).Ada hubungan yang bermakna antara kebiasaan olahraga dengan kejadian 
hipertensi pada pasien lanjut usia di Puskesmas Kelayan Timur Banjarmasin tahun 2012 ( $p=0,000$ ). $\mathrm{OR}=13,417$ menunjukkan bahwa pasien lanjut usia yang melakukan kebiasaan olahraganya baik+sedang mempunyai resiko 13,417 lebih kecil menderita penyakit hipertensi daripada pasien lanjut usia yang melakukan

\section{DAFTAR PUSTAKA}

Bustan, M.N. 2007. Epidemiologi Penyakit Tidak Menular.Jakarta: Rineka Cipta.

Departemen Kesehatan

RI.2010.Laporan Data

Penduduk Indonesia.Jakarta: Depkes RI.

Indriyani, 2009.Widian Nur.Deteksi Dini Kolestrol, Hipertensi, dan Stroke. Jakarta: Milestone.

Muhammadun AS.2010.Hidup Bersama Hipertensi Seringai kebiasaan olahraganya buruk.Hasil penelitian ini dapat dijadikan sebagai bahan masukan untuk meningkatkan pemahaman pasien tentang penyakit hipertensi sehingga pasien dapatmembiasakan berolahraga teratur seperti jalan sehat dan mengikuti senam lansia. Darah Tinggi Sang Pembunuh Sekejap. Jogjakarta: In-Books.

Notoatmodjo,

Soekidjo.2005.Metodologi

Penelitian Kesehatan.Jakarta: Rineka Cipta.

Puskesmas Kelayan

Timur.2011.Laporan Tahunan Banjarmasin.Puskesmas

Kelayan Timur.

Puskesmas Kelayan

Timur.2012.Laporan Bulanan Banjarmasin.Puskesmas Kelayan Timur. 